\title{
A Call out of Seir: The Meaning and Future of US Labor Law
}

Christopher Tomlins

Richard Bales and Charlotte Garden, eds, The Cambridge Handbook of US Labor Law for the Twenty-First Century. Cambridge, UK: Cambridge University Press, 2020.

The Cambridge Handbook of US Labor Law for the Twenty-First Century decries federal labor law for forsaking American workers and undermining American unions. Its contributors seek a reformed labor law for the current century. In this review essay, I examine the handbook's contention that federal labor law has failed. To assess the merits of the claim, we must test the foundations of its contributors' assumptions-about the labor movement, about the place of the labor movement in the political economy of American capitalism envisaged by labor law, and, indeed, about law itself. To do so, I turn to earlier, critical research on the character of American labor laws, notably Joel Rogers's seminal 1990 essay "Divide and Conquer," and also to work of my own. To put it crudely, I ask how much labor law reform actually matters.

A call comes out of Seir in Edom: Watchman, how much longer is the night? The watchman speaks: The morning cometh, but it is still night. If ye will enquire, come again another time.

- Max Weber, "Science as a Vocation," after Isaiah 21:11-12 (translated by

Thomas Kemple $(2014,174)$

\section{INTRODUCTION}

Handbooks are a symptom of the contemporary publishing economy. Publishers are particularly fond of handbooks because they furnish a reliable product at very low cost per contribution (customarily, the marginal print copy, like a frequent flyer mile). Handbooks furnish authoritative, electronically enriched content dumped into a database and sold by subscription to research libraries as ready reference tools, or rented by the fragment to individual users. As a result, there is (now) a handbook for everything, so that to browse handbook series is to encounter titles of such arcane exactitude as to defy caricature. Who knew there was a Routledge Handbook of Reliability, Availability, and Maintainability Standards and Specifications in Railway Systems?

By such standards, The Cambridge Handbook of US Labor Law for the TwentyFirst Century (hereinafter Handbook) is positively worldly in imaginative scope

Christopher Tomlins is Elizabeth Josselyn Boalt Professor of Law, School of Law, University of California, Berkeley, United States, Email: ctomlins@law.berkeley.edu

My thanks to Catherine Fisk for helpful comments. 
(Bales and Garden 2020a). This Handbook departs the genre in another respect as well. Because they are in large part works of reference, handbooks are mostly retrospective. They offer summary and shape to an existing field of scholarly or general interest. As its title suggests, The Cambridge Handbook of US Labor Law for the Twenty-First Century is not retrospective but, rather, normative and prospective. Although its contributors build their essays on the foundations of what is and, to a more limited extent, what has been, their eyes are lifted to the horizon of what should be. To a degree, one can attribute this palpable exhibition of longing to professional socialization. Almost all of the thirty-seven contributors are lawyers, ${ }^{1}$ and legal scholarship is wedded to prescriptive recommendation. But there is a particular edge to the longing that defines this Handbook. In part, this is a matter of history and, in part, a matter of practice.

US labor law, as it is understood by virtually all of the Handbook's contributors, is a legal genre invented in the 1930 s. $^{2}$ It is the law of collective labor organization, action, and bargaining associated with the National Labor Relations Act of 1935 (Wagner Act), as administered by the National Labor Relations Board (NLRB), interpreted by federal courts, and amended by Congress, principally in the Labor-Management Relations Act of 1947 (Taft-Hartley Act). ${ }^{3}$ As such, US labor law's origins are associated with the expansive, reforming, quasi-social democratic ethos that American history assigns to the New Deal regime of Franklin Delano Roosevelt and with the legislative reinvention of the organized labor movement that American labor history traditionally identifies as perhaps the single most notable sociopolitical development of that epoch (see, for example, Leuchtenburg 1963, 106-14; Bernstein 1971; Rodgers 1998, 409-84).

If we characterize the labor movement reinvented in the 1930s as the first mass "social movement" in the sense adopted by modern socio-legal scholarship (see Fisk and Reddy 2020), "labor law" as conceived by the Handbook identifies the means by which that movement was granted the capacities necessary to fulfill the role of agent for the satisfactory realization of crucial public ends. To that extent, one can identify labor lawyering as the original expression of modern public interest lawyering-a legal practice undertaken to assist the poor, the marginalized, and the exploited, a practice in pursuit of change in social and economic policy in the public interest rather than in the interest of elite advancement or private profit. Like civil rights, labor law is where public interest and social justice meet and merge; labor law scholarship becomes one of the first legal spheres in which an academic intelligentsia has applied itself to the perfection of a jurisprudence devoted to the adjustment of putatively antagonistic interests (capital and labor), to the general benefit of those who are by the practicalities of their situation individually without the capacity to help themselves. Political liberalism and practical commitment are the two strong threads that run through virtually all of the Handbook's contributions.

It is no news to anyone that, as of now, the organized labor movement shaped by twentieth-century liberal labor law lies in tatters. By whatever measure of strength and

1. To be precise, all but three (two economists and one sociologist) have juris doctor (JD) degrees, and, of those with JD degrees, all but two (one foundation fellow and one industrial and labor relations lecturer) have (or had) law-teaching appointments.

2. The one contributor who clearly stands outside this generalization is Richard A. Epstein.

3. National Labor Relations Act, July 6, 1935, 49 Stat. 449 (Wagner Act); Labor-Management Relations Act, June 23, 1947, 61 Stat. 136 (Taft-Hartley Act). There are many guides to the substance of the labor law genre. My personal favorite remains Taylor and Witney ([1971] 1979). 
impact-raw membership figures, union density, the standing of unions in American politics and culture, the distribution of wealth in American society-the labor movement is a shadow of its former self. The objective of the Handbook's authors is its refurbishment. Their premise is that the twentieth century's innovations in labor law failed. ${ }^{4}$ The current state of the organized labor movement in particular, and of wealth inequality in general, is proof of that failure. The range of their proposals is wide, but their shared purpose is to remedy the law's failure to secure the collective processing of disputes over wages and working conditions arising in the normal course of development of a mature industrial economy. In this effort and commitment, the Handbook is truly a representative microcosm of the scholarly field that it summarizes.

The commitment of the Handbook's authors and editors to industrial justice is clear and welcome. The argument that the law has failed, however, makes sense only if we accept that the purpose of labor law, as expressed in its statutory texts and in its administrative and juridical decision making, has been to create something other than the labor movement that exists at this point in the early twenty-first century. Their prescriptions for change, likewise, make sense only if we accept that law per se possesses the capacity (and the intention) to create the other for which the authors long. Both assertions are questionable. To assess the merits of the Handbook's assertions and desires, we must test the foundations of its contributors' assumptions_-about the labor movement, about the place of the labor movement in the political economy of American capitalism envisaged by labor law, and, indeed, about law itself. To do so, this article will turn to earlier, critical research on the character of American labor laws, notably Joel Rogers's (1990) seminal article "Divide and Conquer." Crudely put, we will ask whether labor law reform matters.

\section{THE SHAPE OF THINGS}

In 2019, some 14.6 million wage and salary workers belonged to American unions, an overall union membership rate (otherwise known as union "density") of 10.3 percent. The union membership rate of public-sector workers was 33.6 percent (7.1 million members), compared to 6.2 percent for private-sector workers ( 7.5 million). Men had a higher union membership rate (10.8 percent) than women (9.7 percent). Black workers (12.7 percent) were more likely to be union members than White (11.5 percent), Hispanic (10.2 percent), or Asian (10 percent) workers (US Bureau of Labor Statistics 2020).

Unions do more than bargain for their members. To gain recognition as a bargaining agent, a union must first win the support of the majority of all of the employees in a "unit" designated "appropriate" for collective bargaining by the National Labor Relations Board. The standard mechanism for testing majority support is a board-supervised representation election. A union that wins a bargaining unit election becomes the "exclusive" bargaining agent for all of the employees in the unit, whether they are members of the union in question or not and whether they voted for the union or not. In 2019, 16.4 million wage and salary workers (11.6 percent) were represented by a union, indicating that the direct effect of the extension of union contracts beyond union

4. For two lengthy essays along these lines, each replicated in truncated form by its author as a Handbook contribution, see Estlund 2002; Andrias 2016. For the claim that US labor law has not simply failed but has been actively sabotaged by administrative fiat, see Morris 2012. 
members facilitated by the current collective bargaining regime is modest. We should note that the raw wage premium attributable to union representation is substantial. Nonunion workers had median weekly earnings that were 81 percent of the earnings for workers who were union members (US Bureau of Labor Statistics 2020). This differential alone helps to explain the high levels of employer antagonism to unions that are characteristic of the United States.

Forty years ago (1983 is the first year for which directly comparable US Bureau of Labor Statistics data is available), 17.7 million workers belonged to unions, a union membership rate of 20.1 percent, which is almost double that of today (US Bureau of Labor Statistics 2020). The 1983 figure, however, already represented an organized labor movement deep in crisis. Overall union density remained above 20 percent only because a rapid increase in public sector union membership from a membership rate of 10 percent in 1960 to 40 percent in the late 1970s had partially offset a thirty-year decline in private sector density (Schmitt 2013). Measured by overall union density, peak union strength had actually been reached in 1953, when union membership of 16.4 million accounted for 33 percent of nonagricultural employees (26 percent of the civilian labor force) (Troy 1965, 1, 2). Measured purely by membership, the high point of twentieth-century union strength was 1979 when American unions had twenty-one million members, but this number represented a significant retreat from the 1953 union density rate, to 24.1 percent. $^{5}$ Both overall membership and overall density have declined continuously ever since (Hirsch and Macpherson 2020).

Over the same long postwar arc, we have seen a stark reversal of established trends in the concentration of wealth. Since the 1980s, as Thomas Piketty (2020) has established, socioeconomic inequality has increased throughout the world. Nowhere among highly developed economies, however, has wealth inequality increased as rapidly as in the United States, where the compression of wealth inequality that occurred between 1940 and 1980 reversed during the 1980s and has now returned to levels last seen in the 1920 s and early 1930s. The correlation of union growth with the compression of wealth inequality, and union decline with its explosive restoration, is strong $(1-2,16-23,29-$ 30; in general, 415-716; Gordon 2016, 605-39). ${ }^{6}$

The single most convincing account of the course and meaning of the organized labor movement's developing crisis between its moment of peak strength in the mid1950s and its tipping point in the late 1970s is that offered in 1990 by Joel Rogers (1990). Rogers's "strategic and institutionally-grounded" comparative analysis of labor relations in the United States distinguishes between two distinct logics of union organization and collective bargaining common to capitalist democracies: a low-density decentralized case (LDDC) and a high-density centralized case (HDCC). Each case is premised on the foundational existence of inter-capitalist competition, which Rogers holds "analytically prior" to capitalist-worker conflict. Each describes a distinct

5. Troy's (1965) figures suggest that density had fluctuated during the early years of the intervening period, before beginning a slow but steady decline at the end of the 1950s.

6. See also Leonhardt and Serkez 2020, comparing the relative share of total national income flowing to corporate profits and worker pay in the United States and Europe from 2000 to 2015 (relatively constant in Europe, changing substantially in favor of profits in the United States) as well as the ratio of chief executive officer to worker pay, in which, as Piketty $(2014,298-300)$ has shown, the United States is an extreme outlier. 
outcome in the impact that worker organization has had on that conflict. Simply put, "the organization of workers can, by changing the terms of capitalist competition, also alter the terms of conflict and exchange between workers and employers" (144-45).

Terms of capitalist competition change when unions achieve sufficiently high density in the relevant product market to take labor costs out of competition. The result on both sides is altered strategic behavior and, concomitantly, the introduction of structural innovations, transforming the prevailing institutional and strategic circumstances of labor relations from those that are characteristic of the LDDC to those that are characteristic of the HDCC: "[U]nions exchange militant economism and job control for political exchange and cooperative strategies, and employers recognize both that they must, and can, live with unionization. Instead of devoting themselves to rolling back unionism, or keeping it cabined within distinct limits, they cooperate in its maintenance and extension" (Rogers 1990, 144-45). The highest stage of the HDCC is national-level agreements between centralized federations of unions and employers, the terms of which are extended throughout the industry or industries in question; the transfer of a widening array of labor costs (for example, health care) to the "social wage" prescribed in legislation and funded by the state through taxation; and the institutionalization (and defense) of both social wage and peak-level cooperation through political activity. ${ }^{7}$

Applying his LDDC/HDCC logics to the US case, Rogers (1990) was able to show that the pattern of post-Second World War labor relations in the United States conformed overwhelmingly to low union density and structural decentralization. Historically, American unions on occasion have been able to achieve sufficient density of membership in specific regions or industries to take wages out of competition, resulting in the adoption of modes of cooperation and political action characteristic of the HDCC, but these exceptions to the prevalence of low union density and decentralized bargaining have always proven temporary and only weakly institutionalized. ${ }^{8}$ The best examples of exception are to be found in those "core" components of the private sector (mass production manufacturing, transport and communications, construction) where union organizing drives in the 1930s either consolidated prior decentralized presence or achieved presence for the first time, and where union presence was institutionalized during the Second World War. ${ }^{9}$ In this private sector "core," union density was not seriously assaulted until the terms of capitalist competition and state accommodation of collective bargaining were decisively altered on a world scale by the "oil shock," fiscal crisis, and stagflation economy of the 1970s and the attendant internationalization of

7. For examples, see German and Swedish codetermination, described by Thomas Piketty (2020, 49598), and peak association bargaining, described by Joel Rogers (1990, 77). The best modern Anglosphere example is likely the Australian "Prices and Incomes Accord," established in 1983 and prevailing, in successive revised forms, until 1996, negotiated between the Australian Council of Trade Unions and the Australian Labor Party governments of Prime Minister Bob Hawke and Prime Minister Paul Keating, with employer acquiescence. The accord period ended with the formation of the Howard Liberal Party-National Party Coalition government in 1996, which saw the adoption of "free market" policies in wage determination, the destruction of the conciliation and arbitration system in favor of "enterprise bargaining," and, in general, a rapid growth in government hostility to the union movement in Australia.

8. For an important early example, see Kazin 1987.

9. For examples of consolidation, see Christie 1956; Garnel 1972. See generally Tomlins 1979. For examples of new penetration, see Bernstein 1971, 217-317, 432-634. On the effects of the Second World War, see Lichtenstein 1982. 
capitalist competition and crisis. That said, the American labor movement's high-density core was brittle-vulnerable at all times to a labor relations culture historically, legally, and politically attuned to the default American reality of low density and decentralization. In the 1970s, when the terms of capitalist competition in the private sector core turned against the limited postwar accommodation of unions, the result was reversion to the American mean.

Rogers's (1990) account, it will be clear from this description, was macrostructural. It was premised on an indubitably radical account of the inherently exploitative character of work in a capitalist economy, but it emphasized that action on both sides of the capital/labor divide was characterized by rational choice in determining strategy and in mobilizing available resources, rather than dictated by class position or received ideology. As this suggests, Rogers favored explanatory parsimony over "causal promiscuity," a commitment that led him to adopt an entirely instrumental explanation of the legalinstitutional history of US labor relations in the years following the Second World War: "Arising from a decentralized bargaining system, [private sector labor regulation] confirmed decentralization; forged in an environment of low union density, in which unions occupied just a few sectors of the economy, it did nothing to encourage the spread of unionization beyond those sectors" (3n6, 93-94, 118-19).

In other words, the labor relations system that prevails in the United States is not a consequence of law's failure but, rather, the intended outcome: "There is little mystery here. ... The fit between the law and the institutions it orders is tight as a glove. I merely describe the cloth" (Rogers 1990, 119). Conventionally, the legal structure of postwar collective bargaining in the United States is seen as the product of the conservative reaction to the New Deal's 1935 Wagner Act, as set forth in the 1947 TaftHartley Act, but Rogers suggests otherwise: “As pertains to law, I am most concerned with how the general structure of the legal regime shaped the formation and pursuit of interests. While the law has been considerably refined over the past 40 years, that structure was clearly apparent by 1947, if not 1935" (3n7; emphasis added). ${ }^{10}$

Rogers's account in "Divide and Conquer" was "entirely critical" and bereft of normative reflection and recommendation. Accepting that "explicit consideration of the structure of an alternative system of labor law and labor relations would seem a natural successor to the present effort," Rogers $(1990,147,147$ n426) indicated that consideration of that alternative was in progress in a book he entitled Organizing Interests: Unions, Workers, and American Labor Policy. But the book never appeared. Conceivably, Rogers abandoned the exploration of alternatives because its only possible course could have been an exercise in utopianism. His explanatory parsimony had reduced the issue, elegantly but essentially, to one key variable. Labor and capital vie for shares of the product of the enterprise that they jointly maintain in continuing existence-the "going concern." 11 Capital can be reconciled to the share that labor takes only if the cost of that share is taken out of competition-that is, only if capital

10. I draw attention to this point because it comports with arguments that I presented at length in Tomlins 1985a. This was a book with which Rogers advertised "differences" that he promised to explore in a future commentary on "The State of Labor Theory," which in his 1990 essay he described as "forthcoming" in Law $\mathcal{E}$ Social Inquiry. See Rogers 1990, 84n223. Sadly, that commentary never appeared. No doubt, I would have learned from it, but life goes on.

11. I borrow this term from Commons 1924. 
is enabled to pass that cost on to the citizenry at large, whether directly, as consumers, or indirectly, as taxpayers - rather than absorbing it itself. Direct absorption places the individual capitalist at a disadvantage vis-à-vis competitors, which is intolerable.

How then is labor organization to be reconciled with the elemental reality of capitalist competition? The best that liberal labor law has ever offered is a form of rights talk - a countervailing right of organization that tempers the excesses of the capitalist's proprietarian right to turn a profit by enabling employees to exercise "actual liberty of contract" through "full freedom of association." 12 In the United States, however, force has been a constant in the resolution of conflicts between liberalism's equalized rights, precisely because America's historically anarcho-capitalist political economy breeds hostility to labor organization for all of the reasons that Rogers's (1990) macrostructural analysis offers (see, for example, Auerbach 1966; White 2016). If labor cannot create the conditions in which its share can be passed on-in effect, socialized-then force decides. ${ }^{13}$ Even in the high-density centralized case from which force has been excluded, or at least in which force is ritualized, American unions remained hostage throughout their brittle and temporary ascendancy to the requirement that they continuously demonstrate their capacity to exclude labor costs from competition among all relevant employers. The internationalization of competition destroyed that capacity. Globalization, the successor to the "internationalization" of the 1970s and the neoliberalism that has been globalization's main imprint, have extended the destructiveness of competition. Globalization has meant that the world's multiple national economies have ceased to reproduce the conditions favorable to the high-density case, and neoliberalism has championed "labor market reform." Everywhere, organized labor increasingly lives under the hammer of anarcho-capitalism. ${ }^{14}$

Though Rogers did not follow up, the authors and editors of the Handbook have now provided us with their account of the structure of labor law and labor relations in the United States and have included a host of alternatives to what currently prevails. To what extent can we identify among these alternatives arguments that move us beyond Rogers's (1990) instrumentalism? Is labor law determined or determinative? Can law reform alter the realities that Rogers described?

\section{COLLECTIVITY AND BARGAINING}

The Handbook of US Labor Law for the Twenty-First Century performs several valuable roles: it is a primer on the current state of the organized labor movement and on the economic, political, social, and cultural consequences of its weakness (Bales 2020; J. Rosenfeld 2020); it summarizes the state of the field, both of current labor law and of scholarly debate about that law (Andrias 2020; Epstein 2020; Estlund 2020;

12. For the Wagner Act's market language, see Wagner Act, s. 1. On proprietarianism's twentiethcentury crisis and its neo-proprietarian restoration, see Piketty 2020, 414-716.

13. The analogy with China Miéville's (2006) historical analysis of international law in Between Equal Rights is intentional.

14. See note 8 above. One should note the contrast between antagonism to organized labor prevailing throughout much of the Anglosphere during several decades of "labor market reform" and the higher incidence of high-density centralized case conditions in much of the European Union (EU). British exit from the EU (and its primary motivation) heightens the contrast. 
Gould 2020; Garden 2020a; Hodges and Malin 2020; Kahlenberg and Marvit 2020; Paul 2020); it confronts the ongoing transformation of work and the workplace, notably the disintegration of the twentieth-century Fordist (mass production) corporation, its replacement by the "fissured" (subcontracted) workplace and strategic human resource management, the growth of the individualized "on demand" (gig) economy, and the attendant transformation of the employment relationship (Cherry 2020; DauSchmidt 2020; J. Hirsch 2020; Oranburg and Palagashvili 2020; Slater 2020; Stone 2020); it provides examples of particular inflexibilities in current labor law that impinge on the organization of workers and the creation of sustainable collective bargaining relationships (Compa 2020; Crain 2020; Garden 2020b; Getman 2020; Lofaso 2020; Oswalt 2020; D. Rosenfeld 2020; Saucedo 2020; Secunda 2020); and it offers arguments stressing the necessity of labor organization-the voluntary association of workers-to any robust conception of civil society and economic democracy (Bodie 2020; Dimick 2020, 351-60; Fernández-Villaverde 2020; Fisk 2020; Garcia 2020; Green 2020; Morris 2020; Narro 2020; B. Rogers 2020; Rosado Marzán 2020). In assembling such a large and diverse group of contributors, the Handbook can realistically claim to represent the best of what is on offer in addressing all of these crucial topics for discussion and action.

The Handbook's guiding contention is that there is a direct relationship between the long decline in union density that we have already surveyed and the prevailing regime of American labor law. The purpose of the Handbook is to advance a reform agenda that far transcends the "traditional fixes" proposed in legal and industrial relations scholarship. ${ }^{15}$ As explained in the preface, "the general premise is that American labor law should be reconsidered and reformed, in ways both incremental and radical, but in all cases with the overall goal of protecting workers, even as the economy and the nature of work are changing rapidly" (Bales and Garden 2020b, xv). That said, the collection is exceptionally varied, and the editors make no attempt to create priorities amid the variety. The collection identifies "many paths forward" and its proposals "are not always consistent with each other." It is left to readers "to decide for themselves how the law should best respond to the crisis that American labor is facing" (xv).

It is a truth of scholarly collaborations like the Handbook that, confronted in what they hope will be a shared project with the ineluctable variety of scholarly opinion, editors must always make the best of what they have been offered. Their contributors are united, these editors assure us, in their concern for the well-being of American workers. ${ }^{16}$ Still, their promise that herein lies a coherent agenda for fundamental reform of the prevailing regime of labor law dies before the end of the preface. It is as though labor law scholarship has reproduced within itself the characteristics of the LDDC-decentralization and exceptional fragmentation-that make up the structural reality of organized labor in the American case.

15. The essay that comes closest to exemplifying "traditional fixes" is that of former National Labor Relations Board chairman William B. Gould IV (2020).

16. Bales and Garden 2020b, xv. This is a bar set necessarily low because the collection includes contributions from authors who do not agree with the editors' prefatory statement that the effects of union decline are "deeply troubling" and who are instead of the view that the well-being of American workers is in fact better served by the disappearance of labor organization. See Epstein 2020. Similarly, on the irrelevance of labor unions in the gig economy, "where many of the problems that traditional unions sought to solve do not exist," see Oranburg and Palagashvili 2020, 194, 179-95. 
The absence of a coherent agenda, in my view, results from the absence of a sufficient analysis of the problem that the Handbook desires to remedy-namely, the decline in union density, uninterrupted for fifty years, and its relationship to the prevailing regime of labor law. The clearest sign of this absence lies in the title to Part 2 of the Handbook, in which ten essays furnish the Handbook's core by debating the current labor law regime: "Labor Law Is Out of Date." Part 2's lead essay, by Cynthia Estlund $(2020,25)$, contends that labor law is dysfunctional because it is obsolete: "The existing labor law framework was formed in an economy dominated by large, integrated, capitalintensive firms." This economy has disappeared: "Today, hypermobile capital, fissured production networks, deregulation, and globalized competition have utterly transformed the landscape of work." Failure to reform the law has rendered it ossified and ineffectual in today's economy $(25,25-33)$. One must ask, however, whether labor law is indeed ineffectual? If one's criterion is an effective organized labor movement and one believes "labor law" should be defined as a set of techniques designed to produce a strong and effective organized labor movement, then one has grounds for believing current labor law is ineffectual. But if one's criterion is an ineffective and weak organized labor movement and one believes labor law is best defined as that set of techniques tending to that end, then one must conclude that the current regime is highly effective. Certainly, by arguing that labor law is "out of date" one is arguing that it should be other than it is. But a purely temporal register neglects the question "why" the labor law regime is as it is. What interests does obsolescence serve? Cui bono?

We have already encountered Joel Rogers's (1990) answer. As long as density fails to reach levels sufficient to take labor costs out of competition, it will be in employers' interests to oppose labor organization and to endorse a labor law regime that discourages the organization of labor. A variation on the same answer, which adds ideological bite to Rogers's cold equation, can be found in Richard Epstein's (2020) essay “Combatting Union Monopoly Power" in the Handbook. Epstein's presence justifies the editors' contention that the Handbook "brings together scholars from all sides of the political spectrum"- - he is, in effect, the Mad Hatter at this particular tea party-but it has the merit of underscoring the political exceptionalism of the otherwise fairly solid phalanx of liberal argumentation that the Handbook offers, while also allowing one to question whether Rogers's cold equation is quite as determinative as he thinks.

Unions are, necessarily, a liability on capital. Their reason for being is to moderate, as far as possible, the rate at which employers extract surplus from labor. In the lowdensity case, their strategy is akin to guerilla warfare-militant economism and job control. ${ }^{17}$ In the high-density case, their strategy is one of peak association agreement and extension. The ultimate in HDCC extension is the political shunting of collectively bargained labor costs into a social wage. The logic of Rogers's (1990) argument is that employers will "flip" from antagonism to toleration at the point at which unions have achieved sufficient density to take labor costs out of competition. This suggests that there is nothing so supremely self-interested as capital, extending even to the toleration of intrusions upon its own freedom of action. Epstein brings to the argument the ardor of a free market ideologue, which reminds us that capital's decisions may not always be as

17. The terms are from Rogers 1990, 145. The phenomenon, however, was noted long ago, in 1931, by Louis Adamic ([1931] 2008, 75-182). 
dispassionately functional as Rogers's equation suggests. Epstein, naturally, "regard[s] the decline of the union movement as welcome and overdue" because, unlike Rogers and unlike Rogers's HDCC employers, any intrusion upon an employer's command and control of economic coordination is to be resisted. ${ }^{18}$ As Sanjukta Paul's (2020) rebuttal to Epstein in the Handbook underscores, "firms," no less than unions, are cartels that attempt to monopolize economic coordination. But Epstein is committed to a theory of the firm that refuses to distinguish between "firms" and "persons" or to admit that aggregations of capital (firms) are quite as "collective" in their character as aggregations of labor (unions).

Epstein's (2020) essay is valuable, notwithstanding that one may disagree with its thrust, because, in flaunting a position ideologically adverse to the vast majority of the Handbook's contributors, it throws their tendency toward liberal consensus into sharp relief, which in turn renders questionable arguments that the solution to organized labor's problems lies in updating an "old and creaky" statutory schema. Epstein reminds us that we are dealing here not with a dysfunctional legal regime but, rather, with a stark question of distribution — of wealth and power - and that there is presently no political constituency of sufficient influence to undertake the desired "repurposing" of US labor law. The Big Battalions like things the way they are, which is "an ever-expanding network of contracts that allows for a more accurate and a more rapid readjustment of the factors of production-both material and human-needed to complete any particular project" (86). ${ }^{19}$

Epstein's (2020) essay is also valuable in that it is practically the only contribution to embrace some form of historical perspective on the issues under discussion. My appreciation of Epstein's historical sensibility does not extend to trust in its argumentative substance-Epstein's misrepresentation of the work of Robert J. Gordon (2016) on productivity, for just one example, is nothing short of astonishing ${ }^{20}$-but its merit is to

18. Epstein 2020, 86; see also Harris 1982. Epstein's $(2020,76)$ defense of his position is based on a historically naive statement of common law "general principles" favoring individual autonomy and contractual freedom that is akin to the embrace of a legally given state of nature. For a recent comprehensive rebuttal of this approach, see Pistor 2019.

19. Epstein's $(2020,86)$ delight at the prospect of a private sector organized by an "ever-expanding network of contracts" is a rather charming echo of the mid-nineteenth-century Victorian ideal embraced by, amongst others, Henry Sumner Maine (1861, 304-6). It also articulates the twenty-first-century ideal of the "gig" economy, on which see also Oranburg and Palagashvili 2020. Unfortunately, the gig ideal is as deceptive a representation of the reality of twenty-first-century "on-demand" work as Maine's "men [left] to settle rules of conduct for themselves" was of nineteenth-century wage work (305). For a critical sociology of the gig economy, see Schor 2020. For critical legal histories of the nineteenth-century Anglo-American labor contract, see Tomlins 1993; Stanley 1998; Steinfeld 2001; see also generally Hay and Craven 2004; Tomlins 2010.

20. Epstein $(2020,79)$ cites Gordon (2016) in support of his contention that, during the early decades of the twentieth century when unions were hobbled by the Lochner era's common law restraints, "increased productivity drove substantial gains in real wages." His purpose is to defend those restraints by implying a causal link between union weakness and rapid growth in productivity. Epstein $(2020,79)$ states further that Gordon's research proves "the overall increase in the standard of living between 1870-1940 was unmatched at any other time in the United States." What does Gordon actually tell us? First, the period he has under examination is not 1870-1940 but, rather, 1870-1970. Second, the particular question Gordon (2016, ix; see also 546; emphasis added) desires to answer "is why productivity growth was so fast between 1920 and 1970 and so slow thereafter." Gordon shows the rate of productivity growth prevailing between 1870 and 1928 doubled between 1928 and 1950 (535), that real wages first began rising above historical trend in the late 1930s and continued to do so until 1973 when real wage growth began to reverse (541-43), that both 
underscore how neatly historical inquiry sustains the close relationship between the "macrostructure" of labor organization and the operative legal regime that Rogers develops. That is, labor organization in the United States has throughout its history manifested the attributes of Rogers's LDDC, a circumstance to which the restricted achievement of high density and centralized bargaining in the post-Second World War "core" represents a temporary and partial exception. ${ }^{21}$ The operative legal regime, whether derived largely from juridical common law prior to the 1930s or from statutory and administrative law thereafter, has conformed to that reality.

We can take this contention one developmental step further, to the very nature of the labor law regime that liberal (and radical) labor law scholarship has idealizednamely, the original 1935 Wagner Act and its early administration. Epstein (2020) excepted, to the extent that the Handbook manifests a historical consciousness, it is one in which labor history, and the history of labor law, begins with the passage of the Wagner Act. This is understandable - the focus here is on statutory and federal law, and, in any case, the Handbook is trying to look forward. ${ }^{22}$ But the particular virtue of history is critical perspective. In labor history, and in labor law history, the Wagner Act and the conjoined Congress of Industrial Organizations (CIO) have long performed the role of "the one good thing that happened to labor in American history." One really needs to get past this rather simplistic nostalgia in order to understand how and why the labor movement largely failed to make the transition to high-density organization and centralized bargaining that, in Rogers's (1990) analysis, could have secured it lasting institutional acceptance in a capitalist economy.

Begin with the American Federation of Labor (AFL), usually the villain of the piece. Created in 1886, the AFL was the first and, for fifty years, the only permanent federation of American labor organizations. In structure, strategy, and ideology, the AFL was a creature of Rogers's (1990) LDDC. That is, in intent, if not always in action, its affiliated members were militantly economistic organizations that embraced strategies of job control—indeed, job ownership — and autonomous self-reliance. Their strength, at times considerable, was concentrated in local product markets where, on occasion, they were able to achieve sufficient density of membership to take labor costs out of competition. In some of those localities, one can observe moves toward forms of semi-institutionalized peak association bargaining and forms of political behavior presaging the establishment of a social wage, characteristic of the HDCC (see, for example, Kazin 1987). But these islands of strength were always vulnerable to the constant extension of markets and, hence, the renewals of capitalist competition that accompanied the ongoing consolidation and spatial extension of capital in cartels, trusts, and, eventually, national-level corporations. The patchwork character of local strength ensured the AFL

productivity and real wage growth rates are attributable not to union suppression but, rather, at least in part, to New Deal legislation that made it much easier for unions to organize $(537,542-43)$, and that the decline in unionization since the early 1970s is one significant factor amongst others in the stagnation of real wages and productivity (605-15). These conclusions, says Gordon, are matters of "elementary economics" (537), informed by "basic economic theory" (541).

21. The fragmented, low-density, and decentralized character of labor organization mimics the political economy of American capitalism - a vast country of varying demographic density, a historically regionalized and decentralized economy, and a highly decentralized political structure.

22. This tendency is perhaps most noticeable in Andrias 2020, which essentially writes off the twentieth century's labor movement and its collective bargaining regime altogether. 
remained a decentralized federation; structural decentralization also characterized the majority of its affiliates. All of this translated into a voluntarist ideology that was deeply suspicious of state institutions (notably, the judiciary) and state action. Ideologically, one can characterize AFL voluntarism as a conservative form of syndicalism (this history is traversed in Tomlins 1985a).

All this might lead one to suppose that the AFL and its member organizations were increasingly irrelevant to the direction of American economic development. Indeed, this used to be (perhaps still is) the orthodoxy of American labor history, which depicted the AFL as an antediluvian fossil federation of reactionary "craft" unions, always destined to be overtaken by dynamic industrial unionism. That depiction grows out of the AFL-CIO conflict of the 1930s: the split in the labor movement and the creation of the Committee for Industrial Organization (which later became the Congress of Industrial Organizations) effectively determined the narration of twentieth-century American labor history for at least the next fifty years. In fact, AFL unions in the 1930s were not committed to a "craft" form of organization. Leading affiliates had long since exhibited a significant degree of institutional flexibility and a capacity for structural and jurisdictional innovation that responded to alterations in the technological and economic environments in which they operated. When the political and economic circumstances of the 1930 s created a moment favorable to union growth, AFL unions grew just as rapidly as CIO unions (Tomlins 1979).

The point of this digression is not to rake over the coals of old scholarly disputes. The point is to clarify the moment of reception of the Wagner Act. ${ }^{23}$ Precisely because, for much of its fifty-year history prior to the act's passage, the existing organized labor movement had been reasonably tenacious rather than pulseless in its pursuit of organizational survival and growth, it had vested interests in forms of institutional organization, behavior, and ideology that collectively comprised a coherent strategic and consequent structural position. That position had developed in constant interaction with, and response to, the political and economic realities of Rogers's (1990) LDDC - localized and often transitory pockets of union strength, rapid technological and organizational change in the structure of economic activity, largely hostile employers seeking to avoid the differential impact of low-density union organization in a given product market, and a political and legal environment that complemented employer hostility. At the moment of opportunity in the mid-1930s, existing unions were loath to surrender to regulatory state determination the strategies and structures they had learned to depend on for survival. For its part, the industrial and labor relations intelligentsia that debated the creation of the New Deal's collective bargaining policy, and, in several important instances, furnished the personnel to undertake its administration, had

23. In his stimulating Handbook essay "Can Labor Law Reform Encourage Robust Economic Democracy?" Brishen Rogers $(2020,329)$ claims that the arguably radical Wagner Act "sparked the most significant unionization drive in [American] history, as the CIO organized most core industries by the outbreak of World War II.” This is par for the course in labor law scholarship. In fact, organizing campaigns had been underway since 1933, and American Federation of Labor unions grew faster than Congress of Industrial Organizations (CIO) unions in the pre-Second World War period; the "core industries" claim makes sense only if one ignores construction and transport and communications; and the CIO position in mass production was not assured prior to the Second World War (see Tomlins 1979). To understand the relationship between labor organizing and labor law, we need to get the history of both right. When we do, we will discover that labor unions are capable of organizing independently of grand liberal legal gestures. 
developed its expertise in observation of, and engagement with, union organization and collective bargaining in the circumstances characteristic of the prevailing LDDC.

Under these conditions, the reception of the Wagner Act by the organized labor movement between 1935 and 1940 was not a moment of unclouded euphoric upsurge. The historian Melvyn Dubofsky $(1994,181)$ is of the view that reception "cost [labor] nothing and promised vast gains." In fact, the record is one of considerable conflict over the Wagner Act's implementation, signifying that major segments of the organized labor movement identified the act as anything but costless. Equally, the record of the act's administration by the NLRB during the same period is one of significant internal disagreement (Tomlins 1985a, 148-243). Both conflicts were grounded in behavior and ideation learned from the experience of fighting for collective bargaining under the prevailing LDDC circumstances and resulted in the reproduction of significant elements of LDDC unionism as national policy, although now-importantly-subject to administrative policing by the NLRB. The effect was to undercut quite significantly such capacity as the Wagner Act offered in facilitating the creation of a HDCC bargaining regime. The undercut was by no means total; as we have seen, by the end of the Second World War (and largely as a result of the war), significant elements of a HDCC bargaining regime had emerged in the mass-production manufacturing, transport and communications, and construction "core" economy. But the core was, let us say, an island continent surrounded by a LDDC ocean.

The labor movement and the collective bargaining regime that emerged from the New Deal were thus both hybrids. The task of the NLRB, clarified well in advance of the 1947 Taft-Hartley Act's amendments to the Wagner Act, was to manage this hybridity. The result was the institutionalization of what existed under the title of "industrial pluralism"- the regime of enterprise-level private ordering endorsed by the industrial and labor relations intelligentsia nurtured under LDDC conditions, supplemented by the administrative mechanisms of the Wagner Act and by continuous administrative and juridical policing of the detail of private ordering undertaken by the NLRB and the judiciary.

In its heyday - the second half of the twentieth century-industrial pluralism connoted a systematic approach to labor relations, informed by liberal political and social theory, whose point of departure was the belief that industrial conflict in democratic capitalist societies is best dealt with through routinized procedures of negotiation and compromise, leading to agreements formalized in contracts between a union "bargaining agent" endorsed in an election by the majority of employees in a NLRB-designated "appropriate bargaining unit" and the employer of those employees (Tomlins 1985b, 19-34). As Katherine Stone (1981), the leading analyst of industrial pluralism, has put it, taken at face value, "industrial pluralism is the view that collective bargaining is self-government by management and labor ... who jointly determine the conditions of the sale of labor power. The collective bargaining process is said to function like a legislature in which management and labor, both sides representing their separate constituencies, engage in debate and compromise, and together legislate the rules under which the workplace will be governed" (1511).

Stone (1981) is fully aware, of course, that it is an error to take industrial pluralism at face value. Even at the height of its influence as a theory of labor relations, industrial pluralism was based on false premises - namely, that in its constructed private ordering 
regime management and labor confronted each other as equal parties whose collective bargaining created an agreement that functioned as a constitution for the going concern. The model was "a false description" that "obscure[d] the real issues and problems posed by the exercise of power in the workplace" (1511). That has always been true, whether in its twentieth-century heyday or now, when the pluralist model remains the animating core of contemporary labor law but, purely by default, discredited, simply staggering on like a zombie. ${ }^{24}$

In part, the pluralist regime is the victim of critique from the left, which emphasizes the falseness of its premises, and from the right, which disdains its interference with the true private ordering that can only be achieved by zealously free markets. But as Parts 4 and 5 of the Handbook valuably instance, the model is also a victim of its own management of the actual process of pluralist private ordering to which it is committed: the extraordinary license that it grants employers and others to oppose union attempts to gain employee sanction (Garden 2020b); its substitution of a formalized conception of "association" for union rights of assembly (Crain 2020); its elaborate confinement of union capacities for economic leverage behind manifold legal restraints and administrative barriers (Lofaso 2020); the range of stalling tactics that it permits employers who have no actual interest in bargaining a contract; and the range of issues that it considers beyond the mandate of bargaining at all (D. Rosenfeld 2020). All of these "issues" are products of pluralism's conceptualization of collective bargaining as a regime of managed conflict in which formal equals inhabit a relationship that is falsely analogized to political competition: "Unions are critically constrained in their exercise of organizational power. Federal labor law carves out a relatively narrow slice of a business's concerns and then requires only bargaining — not consensus or concessions-over that slice. Without particularized market power such as regional monopsonies or trade restrictions, most workers do not have the raw economic might to force employer concessions. When strikes become relatively toothless, good faith bargaining becomes a convivial chat" (Bodie 2020, 300).

Defenders of pluralism's policy of free collective bargaining call for the restoration of "balance" to its framework. Never have so many playing fields been readied for leveling! But even were a reinvigorated pluralism desirable, one runs headlong into the sheer artificiality of normative argumentation: of course, federal labor relations law "should" be other than it is; and pigs may fly. ${ }^{25}$ Better, surely, to confront why the law is as it is than believe that some inherent sense of "fairness" will persuade legislators and administrators to do other than they have done.

\section{ACTIVITY AT THE MARGINS}

The law is as it is for two reasons. The United States is a capitalist economy first and a democracy second. Notwithstanding the clear preference of working people for

24. As such, industrial pluralism is a particular instance of a genus of twentieth-century liberal legal thought that has been effectively repudiated without obvious replacement. For explorations, see DesautelsStein and Tomlins 2017.

25. As Charles J. Morris $(2020,311)$ puts it, "high-sounding proposals" to reform labor law "require Congressional approval, which can't and won't happen in the foreseeable future.” 
representation through collective organization (Freeman 2007), they will not freely receive it while the interests of capital are not served thereby. That is the lesson told both by American history and, more parsimoniously, by Joel Rogers's (1990) analysis of the interrelationship of capitalist competition and union density. The current moment - the moment that has prevailed since the 1970s — is one in which, quite simply, the interests of capital have not been served by the collective representation of working people. The results have been catastrophic, both for working people and for the polity at large, but they have been good for returns to capital. An era of declining inequality in the distribution of wealth and rising standards of living, both fueled in part by the expanding collective organization of working people and by the modest socialization of labor law, has been followed by an era of rapidly increasing inequality in the distribution of wealth and stagnation in standards of living (measured by real wages), both fueled in part by the contraction of collective organization and the dismantling of modestly socialized labor law (Gordon 2016, 535-65, 605-52; Piketty 2014, 199-376; 2020, 648-716; on socialization, see Kennedy 2006). Nor are these simply US phenomena, although the United States has been at their leading edge. Declining union density, legal hostility to collective action, and rising inequality are to be found worldwide (see, for example, Nam 2019).

What, then, is to be done? Amid rehearsals of the detail of union activity in the current moment, the second half of the Handbook (Parts 4, 5, and 6) offers some suggestions. Uppermost is investigation of what may be accomplished within the margins of current law. Anne Marie Lofaso (2020), for example, addresses the long history of legal prohibitions on secondary activity (activity that seeks to pressure the primary employer by influencing the behavior of secondary actors-for example, suppliers or consumers). Undoubtedly effective, secondary activity enjoyed only a brief period of legal toleration during the 1930s and 1940s before the reimposition of restraint in the 1947 TaftHartley Act. Doubting the likelihood of legislative relief, Lofaso points to the existence of "lawful spaces" within the letter of restriction, notably communications and publicity, that unions may "leverage" to spread their message. Lance Compa $(2020,279)$ assesses the potential of international labor law-for example, the International Labour Organization's core standards, the Organisation for Economic Co-operation and Development's guidelines, and transnational trade agreement labor provisions- to "frame" disputes in ways that "shine a global spotlight on abuses in labor law and practice in the United States." Leticia Saucedo (2020) reports on the resistance to attempts to use immigration law to nullify the Wagner Act's protections in the food industry (the proposed Agricultural Guestworker Act). Warning that the act presages "broader industry efforts to curtail the rights of workers," she calls for civil society responses that can unite immigrant workers with the established labor movement in defense of both (290). ${ }^{26}$ Catherine Fisk (2020) considers what future union security (the fiscal terms of incumbency as a bargaining agent that protect the union from free riding) has, particularly in public sector unionism, in the face of continuous legislative and juridical assaults on member dues and agency fees that threaten to "nationalize" the so-called "right to work" (the open shop). Finding little hope for respite, Fisk argues that unions can find security only through continuous organizing: "The next decade will witness

26. Of equal significance are those essays in Part 6 that describe attempts at coalition building outside the realm of "traditional" organizing. See, for example, Rosado Marzán 2020; Narro 2020. 
either their demise or their re-dedication to member engagement and accountability" (336).

Finally, Charles J. Morris (2020) argues for a return to nonmajority (membersonly) collective bargaining (the argument is made at much greater length in Morris 2005). Historically the default practice of American unions, members-only representation was overtaken by provisions in the 1935 Wagner Act that, as we have seen, awarded a union chosen by the majority of employees within a NLRB-designated appropriate bargaining unit the status (and obligations) of exclusive representative of all employees within the unit. ${ }^{27}$ But, although exclusive representation lies at the core of the collective bargaining regime instituted by the 1935 Wagner Act (Tomlins 1985a, 132-40), it does not displace the prior right of self-organization "to form, join or assist labor organizations, to bargain collectively through representatives of their own choosing, and to engage in concerted activities, for the purpose of collective bargaining or other mutual aid or protection," which is the foundational right of free association recognized and endorsed by the Wagner Act and, indeed, juridically and legislatively acknowledged long prior to that act. ${ }^{28}$ Exclusive representation won by recruiting majority support extends collectively bargained terms and conditions beyond a union's members to the generality of an employer's employees. It is not, however, a statutory prerequisite for representation as such, where the representation claimed is for members only. Nor is majority status a statutory condition of recognition for the purpose of nonexclusive representation.

Morris (2020, 318-19) correctly points to substantial evidence of nonmajority bargaining under the aegis of the Wagner Act during the early years of the New Deal collective bargaining policy: "The majority concept ... concerns the ultimate scheme of the Act." Nonmajority bargaining was an "early stepping-stone stage ... a normal and frequently necessary part of a union's maturation." Only later did the collective bargaining regime come to be identified with exclusive representation elections and, thereafter, was held hostage increasingly to unions' faltering capacity to win "hotly contested, unfair, and largely unnecessary, elections" (314, 315). Citing AFL-CIO President Richard Trumka's 2013 statement that, given its current parlous circumstances, "the labor movement must embrace new models of representation that exist outside of traditional unionism," Morris $(2020,312)$ brands members-only representation and bargaining as just such a nontraditional model. But this seems wrong. It is actually a return to what unions historically have done-organized cadres of members outside any state-mandated bargaining regime to exercise rights of association and assembly and to press demands for the improvement of wages, hours, and working conditions. It is not a departure from tradition but, rather, a return to it. As Fisk (2020) emphasizes, it is only through such organizational activities that American unions can recover their strength and purpose.

27. 49 Stat. 449 , para. 9.

28. As, for example, in Massachusetts Chief Justice Lemuel Shaw's careful statement of the limits as well as the extent of the application of the common law of criminal conspiracy to labor combinations in Commonwealth v. Hunt, 45 Mass. 111 (1842). Along with all of the antebellum American labor conspiracy cases, Hunt is discussed in Tomlins 1993, 101-219. For inquiry into labor conspiracy doctrine and the labor injunction in the second half of the nineteenth century, see Forbath 1991; Hattam 1993; see generally Tomlins 1995. 


\section{HOW MUCH LONGER IS THE NIGHT?}

As Saucedo $(2020,281)$ states, "a premise of this book is that labor union organizing must be revived." How? Many Handbook authors choose to lecture Congress on what it should do to facilitate union recovery, but, as should be clear by now, normative argumentation, in my view, is a waste of time. Legislative action requires pressure, pressure requires organization, organization must therefore occur prior to any possibility of legal change. Labor organizations know through long experience that opportunities for collective bargaining will not freely be granted as long as the interests of significant sectors of capital are not served thereby, but this is not the only lesson that American history offers us. American labor history is a history of blood and violence and conflict, of battles for organization and collective self-determination undertaken in the face of capital's opposition. It is not a history of unalloyed failure. Nor is it a history of state dependence - of waiting for the state to reconfigure the operative legal regime to the labor movement's greater advantage. An organized labor movement has been in continuous existence in the United States for the better part of 150 years. Its history is one in which organizations have been built as well as destroyed, in which those organizations innovate as well as stagnate. It is a history at times of insular self-reliance and at other times of national political action. It is a history that began long before there was such a thing as a federal collective bargaining policy and that is in no sense dependent upon that policy for its continuation because it is a history not only of waiting to receive but also of grasping opportunities to take. All of this accumulated experience makes the history of organized labor a useful history, a history worth knowing, a source of strength.

At the end of "Science as a Vocation," the November 1917 lecture from which this essay's title and epigraph are taken, Max Weber ([1917] 1946) contemplated the terms upon which inspiration — charisma-might reappear in a disenchanted, routinized world. They would be terms, Weber said, of engagement: not of watching and waiting, but of acting and working. This was a statement about time, and, as Weber's reference to Isaiah indicates, it was religious time he had in mind. It was a statement about chronos, about duration, the endless night of awaiting the Messiah. But it was also a statement about kairos, the epiphanic, uncertain, instant in which the Messiah actually appears: "From this we want to draw the lesson that nothing is gained by yearning and tarrying alone, and we shall act differently" (Gerth and Mills 1946, 156).

To translate Weber's advice into the idiom of American labor history is to arrive at the slogan "Don't Mourn, Organize!"29 The slogan is a cliché, but a cliché is simply a truth rendered familiar by repetition. The lesson that I have learned from The Cambridge Handbook of US Labor Law for the Twenty-First Century is that this old truth must be repeated again and again because, amid the disorienting miasmas of twentieth century US labor law-the discredited collective bargaining regime that is the Handbook's subject-it has been forgotten. What unions are for (their essence, if you like) is to organize workers. If they do not do that, no matter the odds, then they have no reason for being. For American unions to recover, their density must rise. Density can only rise through organization. Unions can only create that reality themselves. There really is no alternative.

29. Attributed to Joe Hill, November 1915. 


\section{REFERENCES}

Adamic, Louis. (1931) 2008. Dynamite: The Story of Class Violence in America. Oakland, CA: AK Press.

Andrias, Kate. 2016. "The New Labor Law." Yale Law Journal 126: 2-101.

- 2020. "Union Rights for All: Toward Sectoral Bargaining in the United States." In Bales and Garden 2020a, 56-63.

Auerbach, Jerold S. 1966. Labor and Liberty: The La Follette Committee and the New Deal. Indianapolis: Bobbs-Merrill.

Bales, Richard. 2020. "Union Trends." In Bales and Garden 2020a, 3-11.

Bales, Richard, and Charlotte Garden, eds. 2020a. The Cambridge Handbook of U.S. Labor Law for the Twenty-First Century. Cambridge, UK: Cambridge University Press.

. 2020b. "Preface." In Bales and Garden 2020a, xv.

Bernstein, Irving. 1971. Turbulent Years: A History of the American Worker, 1933-1941. Boston: Houghton Mifflin Company.

Bodie, Matthew. 2020. "Organizational Power for Workers within the Firm." In Bales and Garden 2020a, 300-10.

Cherry, Miriam A. 2020. "Contemplating New Categories of Workers: Technology and the Fissured Workplace." In Bales and Garden 2020a, 168-78.

Christie, Robert A. 1956. Empire in Wood, a History of the Carpenters' Union. Ithaca, NY: Cornell University Press.

Commons, John R. 1924. The Legal Foundations of Capitalism. New York: Macmillan.

Compa, Lance. 2020. "Advancing Global Labor Standards: Potential and Limits of International Labor Law for Worker-Rights Advocacy in the United States.” In Bales and Garden 2020a, 268-80.

Crain, Marion. 2020. "Assembly and Collective Rights." In Bales and Garden 2020a, 221-31.

Dau-Schmidt, Kenneth G. 2020. "The Problem of 'Misclassification' or How to Define Who Is an 'Employee' under Protective Legislation in the Information Age." In Bales and Garden 2020a, 140-53.

Desautels-Stein, Justin, and Christopher Tomlins, eds. 2017. Searching for Contemporary Legal Thought. Cambridge, UK: Cambridge University Press.

Dimick, Matthew. 2020. "Union Membership and the Ghent System." In Bales and Garden 2020a, 351-60.

Dubofsky, Melvyn. 1994. The State and Labor in Modern America. Chapel Hill: University of North Carolina Press, 1994.

Epstein, Richard A. 2020. "Combatting Union Monopoly Power: The Contrast between Pre- and Post-New Deal Legal Regimes." In Bales and Garden 2020a, 75-87.

Estlund, Cynthia L. 2002. "The Ossification of American Labor Law." Columbia Law Review 102: 1527-1612.

—. 2020. "Yesterday's Labor Law and Today's Challenges." In Bales and Garden 2020a, 25-33.

Fernández-Villaverde, Jesus. 2020. "The Economics of Minimum Wage Regulations." In Bales and Garden 2020a, 392-401.

Fisk, Catherine L. 2020. "Union Security for the Twenty-First Century." In Bales and Garden 2020a, 336-50.

Fisk, Catherine L., and Diana S. Reddy. 2020. "Protection by Law, Repression by Law: Bringing Labor Back into the Study of Law and Social Movements." Emory Law Journal 70: 63-152.

Forbath, William E. 1991. Law and the Shaping of the American Labor Movement. Cambridge, MA: Harvard University Press.

Freeman, Richard B. 2007. "Do Workers Still Want Unions? More Than Ever." Economic Policy Institute Briefing Paper no. 182, February 22. http://www.sharedprosperity.org/bp182/bp182.pdf.

Garcia, Ruben J. 2020. "Politically Engaged Unionism: The Culinary Workers Union in Las Vegas." In Bales and Garden 2020a, 373-80. 
Garden, Charlotte. 2020a. "Beyond the Race to the Bottom: Reforming Labor Law Preemption to Allow State Experimentation." In Bales and Garden 2020a, 46-55.

—. 2020b. "Tactical Mismatch in Union Organizing Drives." In Bales and Garden 2020a, 199-207.

Garnel, Donald. 1972. The Rise of Teamster Power in the West. Berkeley: University of California Press.

Gerth, Hans H., and C. Wright Mills, eds. 1946. From Max Weber: Essays in Sociology. New York: Oxford University Press.

Getman, Julius G. 2020. "The Central Role of the Right to Strike." In Bales and Garden 2020a, 29199.

Gordon, Robert J. 2016. The Rise and Fall of American Growth: The U.S. Standard of Living since the Civil War. Princeton, NJ: Princeton University Press.

Gould, William B. IV. 2020. "The National Labor Relations Board in the Twenty-First Century." In Bales and Garden 2020a, 34-45.

Green, Michael Z. 2020. "Union Commitment to Racial Diversity." In Bales and Garden 2020a, 38191.

Harris, Howell John. 1982. The Right to Manage: Industrial Relations Policies of American Business in the 1940s. Madison: University of Wisconsin Press.

Hattam, Victoria C. 1993. Labor Visions and State Power: The Origins of Business Unionism in the United States. Princeton, NJ: Princeton University Press.

Hay, Douglas, and Paul Craven, eds. 2004. Masters, Servants, and Magistrates in Britain and the Empire, 1562-1955. Chapel Hill: University of North Carolina Press.

Hirsch, Barry, and David Macpherson. 2020. "U.S. Historical Tables: Union Membership, Coverage, Density and Employment, 1973-2019." http://www.unionstats.com/.

Hirsch, Jeffrey M. 2020. "Twenty-First Century Employers." In Bales and Garden 2020a, 128-39.

Hodges, Ann C., and Martin Malin. 2020. "Public Sector Innovations: Valuing Voice." In Bales and Garden 2020a, 64-74.

Kahlenberg, Richard D., and Moshe Z. Marvit. 2020. "Make Labor Organizing a Civil Right.” In Bales and Garden 2020a, 97-112.

Kazin, Michael. 1987. Barons of Labor: The San Francisco Building Trades and Union Power in the Progressive Era. Urbana: University of Illinois Press.

Kemple, Thomas. 2014. Intellectual Work and the Spirit of Capitalism: Weber's Calling. New York: Palgrave Macmillan.

Kennedy, Duncan. 2006. "Three Globalizations of Law and Legal Thought: 1850-2000.” In The New Law and Economic Development: A Critical Appraisal, edited by David Trubek and Alvaro Santos, 19-73. Cambridge, UK: Cambridge University Press.

Leonhardt, David, and Yaryna Serkez. 2020. "The U.S. Is Lagging behind Many Rich Countries. These Charts Show Why." New York Times, July 2. https://www.nytimes.com/interactive/2020/07/ 02/opinion/politics/us-economic-social-inequality.html?action $=$ click\&module $=$ Opinion\&pgtype $=$ Homepage.

Leuchtenberg, William E. 1963. Franklin D. Roosevelt and the New Deal. New York: Harper Colophon.

Lichtenstein, Nelson. 1982. Labor's War at Home: The CIO in World War II. Cambridge, UK: Cambridge University Press.

Lofaso, Anne Marie. 2020. "Leveraging Secondary Activity within and outside Legal Boundaries." In Bales and Garden 2020a, 232-44.

Maine, Henry Sumner. 1861. Ancient Law: Its Connection with the Early History of Society, and its Relation to Modern Ideas. London: John Murray.

Miéville, China. 2006. Between Equal Rights. Chicago: Haymarket Books.

Morris, Charles J. 2005. The Blue Eagle at Work: Reclaiming Democratic Rights in the American Workplace. Ithaca, NY: Cornell University Press.

—. 2012. "How the National Labor Relations Act Was Stolen and How It Can Be Recovered: TaftHartley Revisionism and the National Labor Relations Board's Appointment Process." Berkeley Journal of Employment and Labor Law 33: 1-72.

— 2020. "Returning Members-Only Collective Bargaining to the American Workplace: How to Restore Labor's Countervailing Power.” In Bales and Garden 2020a, 311-24. 
Nam, Yunmin. 2019. "What Caused the Decline of Labor Unions in 16 OECD Countries? TimeVariant Effects of Globalization and Domestic Politics on Union Density." Journal of Inequality and Democracy 2: 42-62.

Narro, Victor H. 2020. "The Role of Labor Research and Education in the Labor Movement of the Twenty-First Century: The UCLA Labor Center and the CLEAN Carwash Campaign." In Bales and Garden 2020a, 402-15.

Oranburg, Seth C., and Liya Palagashvili. 2020. "Balancing Flexibility and Rigidity: Do Unions Make Sense in the On-Demand Economy." In Bales and Garden 2020a, 179-95.

Oswalt, Michael M. 2020. "The Power of Place." In Bales and Garden 2020a, 208-20.

Paul, Sanjukta. 2020. "The Case for Repealing the Firm Exemption to Antitrust (a Modest Proposal; or a Response to Professor Epstein)." In Bales and Garden 2020a, 88-96.

Piketty, Thomas. 2014. Capital in the Twenty-First Century. Cambridge, MA: Harvard University Press.

- 2020. Capital and Ideology. Cambridge, MA: Harvard University Press.

Pistor, Katharina. 2019. The Code of Capital: How the Law Creates Wealth and Inequality. Princeton, NJ: Princeton University Press.

Rodgers, Daniel T. 1998. Atlantic Crossings: Social Politics in a Progressive Age. Cambridge, MA: Harvard University Press.

Rogers, Brishen. 2020. "Can Labor Law Reform Encourage Robust Economic Democracy?" In Bales and Garden 2020a, 327-35.

Rogers, Joel. 1990. "Divide and Conquer: Further 'Reflections on the Distinctive Character of American Labor Laws." Wisconsin Law Review 1990: 1-148.

Rosado Marzán, César F. 2020. "Principled Hope: Labor Law Reform from an Alt-Labor Perspective." In Bales and Garden 2020a, 361-72.

Rosenfeld, David A. 2020. "Obtaining a First Contract after Winning Recognition." In Bales and Garden 2020a, 259-67.

Rosenfeld, Jake. 2020. "The Consequences of Union Decline." In Bales and Garden 2020a, 12-21.

Saucedo, Leticia M. 2020. "Organizing for Workplace Rights When Immigration Law Discourages It." In Bales and Garden 2020a, 281-90.

Schmitt, John. 2013. "Union Membership Trends, 1948-2012." No Apparent Motive (blog), January 25. http://noapparentmotive.org/blog/2013/01/25/union-membership-trends-1948-2012/.

Schor, Juliet B. 2020. After the Gig: How the Sharing Economy Got Hijacked and How to Win It Back. Oakland: University of California Press.

Secunda, Paul M. 2020. "Captive Audience Meetings: The Right Not to Attend." In Bales and Garden 2020a, 245-55.

Slater, Joseph. 2020. "Some Problems with NLRA Coverage: Independent Contractors and Joint Employers." In Bales and Garden 2020a, 115-27.

Stanley, Amy Dru. 1998. From Bondage to Contract: Wage Labor, Marriage, and the Market in the Age of Slave Emancipation. Cambridge, UK: Cambridge University Press.

Steinfeld, Robert J. 2001. Coercion, Contract, and Free Labor in the Nineteenth Century. Cambridge, UK: Cambridge University Press.

Stone, Katherine V. W. 1981. "The Post-War Paradigm in American Labor Law.” Yale Law Journal 90: 1509-80.

- 2020. "Rupture and Invention: The Changing Nature of Work and the Implications for Social Policy." In Bales and Garden 2020a, 154-67.

Taylor, Benjamin J., and Fred Witney. (1971) 1979. Labor Relations Law. 3rd ed. Englewood Cliffs, NJ: Prentice-Hall.

Tomlins, Christopher L. 1979. "AFL Unions in the 1930s: Their Performance in Historical Perspective." Journal of American History 65: 1021-42.

- 1985a. The State and the Unions: Labor Relations, Law, and the Organized Labor Movement in America, 1880-1960. Cambridge, UK: Cambridge University Press.

—. 1985b. "The New Deal, Collective Bargaining, and the Triumph of Industrial Pluralism." Industrial and Labor Relations Review 39: 19-34.

- 1993. Law, Labor, and Ideology in the Early American Republic. Cambridge, UK: Cambridge University Press. 
—. 1995. "How Who Rides Whom. Recent 'New' Histories of American Labour Law and What They May Signify." Social History 20: 1-21.

- 2010. Freedom Bound: Law, Labor, and Civic Identity in Colonizing English America, 1580-1865. Cambridge, UK: Cambridge University Press.

Troy, Leo. 1965. Trade Union Membership, 1897-1962. New York: National Bureau of Economic Research.

US Bureau of Labor Statistics. 2020. "Union Members Summary." January 22. https://www.bls.gov/ news.release/union2.nr0.htm.

Weber, Max. (1917) 1946. "Science as a Vocation." In From Max Weber: Essays in Sociology, edited by Hans H. Gerth and C. Wright Mills, 129-56. New York: Oxford University Press.

White, Ahmed. 2016. The Last Great Strike: Little Steel, the CIO, and the Struggle for Labor Rights in New Deal America. Berkeley: University of California Press. 